born at Langues, in Lorraine, July 19, 1793. After completing a course of scientific study, he opened a pharmacy in Paris, where he soon attracted attention by his talent for investigation, as well as by his ability in scientific literary work. In $\mathrm{I} 825$ he assumed the editorship of the Journal de Chimie médicale, and continued this labour until some years prior to his death, having as associates Payen, Pelouze, Robinet, Orfila, Péligot, Dumas, and other leading chemists of the day. Soon after entering upon his career as investigator, his merits were recognised by the government, and he gave up his business connections to accept the Chair of Chemistry at the École supérieure de Pharmacie, a position which he occupied up to the time of his death.

Among Chevallier's earlier researches should be mentioned his investigations on the absorptive capacities of living plants for various inorganic solutions, and especially his exhaustive studies in connection with Payne, on the hop and the potato, which attracted general attraction. In physiological chemistry notice should be talen of his detection of various poisonous metals, such as lead and copper, in normal organisms. The knowledge of French mineral waters is also greatly indebted to his numerous and exhaustive analyses, and the presence of arsenic in many springs was first signalled by him. The greater portion of Chevallier's life was devoted to the chemical phases of public hygiene, and in this connection he published a number of valuable papers on the detection and prevention of adulteration in a large variety of articles of food, methods of preserving food, disinfectants, \&c. Of his devotion to the cause of scientific inquiry an interesting anecdote is related from the earlier part of his career. A case of poisoning was to be tried at Paris in which acetate of morphine had been used, and Chevallier, who had sold the salt to the murderer, was summoned as a witness. Anxious to have the full nature of this hitherto untried poison well established, and being limited as to time, he immediately undertook a thorough investigation of its toxic effects on his own system, and succeeded so well that at the trial he was able to give a detailed description of the symptoms attending the use of the drug in question.

As a scientific writer Chevallier was widely and deservedly known. His first work in 1824 , in connection with Payen, "Traité des réactifs chimiques," reached a third edition in five years. In $1826-29$ he published, with Richard and Guillemain, an extensive "Dictionnaire des Drogues simples et composées," in five volumes. In I 850 appeared his admirable "Dictionnaire des Alterations et Falsifications des Substances alimentaires, médicamenteuses, et commerciales," which reached a third edition in 1858 , and was translated into other languages. Other important works were "Recherches sur les Moyens appliquées à la Conservation des Substances alimentaires" (I858), "Du Café, son Histoire, son Usage, etc." (I862); "Traité des Désinfectants sous le Rapport de l'Hygiène publique" (1862).

T. H. N.

\section{THE SEWAGE OF LONDON}

ENERAL SCOTT, in his recent paper at the Society $\checkmark$ of Arts, entitled "Suggestions for Dealing with the Sewage of London," deserves credit for having drawn attention to a subject which in itself must have especial interest for all residents in the metropolis, but which, from the manner in which he has dealt with it, possesses further attractions for those who have made the scientific aspects of the sewage question their study, in that he has really attacked this much-debated problem in an entirely new direction, and has in so far entered upon fresh ground. We do not remember that any previous investigator has set himself the task of examining into the com- position and character of the suspended matters of water carried sewage coupled with the possibility of the mechanical separation by simple subsidence (I) of the heavier mineral particles or the detritus, and (2) of the lighter flocculent particles, which latter, consisting as they do mainly of the fecal matters, possess a far higher manurial value than the heavier substances washed from the roads and pavements.

The sludge deposited from sewage by one or the other systems of precipitation has received hitherto the chief share of attention from scientific men, and even when the possibility of recovering the solid matters in sewage by some system of straining or rude filtration, or the retention of such solids in tanks, in which the sewage is brought to temporary quiescence, has been considered, it seems on all occasions to have been the practice to regard the entire bulk of such deposits as an inseparable compound of very low value from the manure point of view. It is of course the manurial value of the ingredients contained in suspension and in solution in sewage which has been so frequently inquired into by chemists; and, beginning with the report of Dr. Hoffman and Mr. Witt in 1857, down to that of Messrs. Rawlinson and Read in 1876 , a vast mass of valuable information concerning the nature, composition, and value of the manurial elements of town sewage has been accumulated. It has remained for General Scott to point out that-

I. A very large proportion of the solid suspended matters may be removed from sewage by simple subsidence.

2. That such matters may roughly be separated, the more valuable from the valueless, by the method in which such subsidence is accomplished.

3. That after such preliminary treatment, any chemical process for the clarification and partial precipitation of the dissolved impurities of sewage may be carried out far more readily, and under conditions rendering their success in an economical point of view one of greatly increased probability.

4. General Scott has indicated various simple methods for dealing with the silt and detritus removed from the sewage at a relatively small expense ; of deodorising and fitting the sludge obtained by subsidence for the manufacture of a manure ; and lastly, a mode of further purifying the London sewage by a system of chemical treatment whereby it may be rendered suitable for discharge into a river of large volume.

Assuming the dissolved impurities to be incapable of recovery unless the sewage water can be utilised for irrigation, the first object of General Scott's paper was to show how large an amount of harm was done to rivers and the dwellers on their banks solely by the solid matters contained in sewage. By means of extracts from the reports of the various Royal Commissions who have examined into this question, and the information furnished to the Metropolitan Board of Works by their own advisers, Messrs. Bidder, Hawksley, and Bazalgette, he proved that the deposits in the river, the mud banks, the foul emanations from which were most unhealthy, and the dangers to navigation were all due to the discharge of the solid ingredients of raw sewage into rivers and into the Thames.

General Scott next entered very minutely into the composition of the suspended matters of sewage. An estimate of the total weight of solid matters due to a mixed population of $3,500,000$ persons, with a proportionate allowance for the fertilisers existing in the excreta of animals, together with the débris of the animal and vegetable substances which might find their way into the sewers, would manifestly represent the sum total of the organic matters in London sewage.

Concerning the gross annual amount of organic matters different estimates appear to vary very slightly, and in assuming them in the case of London at 50,000 tons per 
annum, there would seem to be but a small margin for error; the quantities of detritus, however, have been very differently stated by the various authorities. From the most reliable analyses of the London sewage, taken at all periods of the day and night, and in many different parts of the metropolis, there appears to be a tolerable unanimity in assigning the ratio of the organic to the mineral ingredient of the suspended matters to be as $I$ is to 2. After a period of settlement it is found that the proportion is, by the subsidence of the heavier mineral particles, exactly reversed, as the larger portion of these valueless components of sewage impurities rapidly subside, entangling with them about $\frac{1}{5}$ th of the organic matters in suspension. General Scott proposes, therefore, a double system of tanks. The first set would consist of a series of shallow catch pits, in which the sewage will only be brought to a state of partial repose, and in which it will part with about four-fifths of the solid mineral matters and one-fifth of the organic matter. In the second set of tanks, in which more time will be given for the settlement of the matters in suspension, the sewage will be deprived of nearly all the remaining suspended impurities, namely, one-fifth of the mineral, and four-fifths of the organic matters. If we assume the gross weight of the organic matters at 50,000 tons per annum, the mineral ingredients will, according to the analyses quoted by General Scott, equal 100,000 tons, and the total of 150,000 tons thus obtained, is, in reality, a very low estimate of the amount of the suspended matters in London sewage. These matters, General Scott is of opinion, he could roughly separate in his tanks thus:- In the detritus tanks he would obtain 80,000 tons of mineral matters, together with I0,000 tons of organic matters; in the second set of tanks he would expect to find about 20,000 tons of mineral matters mixed with about $40, c 00$ tons of organic matters. The exact percentage composition of this latter sludge would, he believes, after studying and comparing many analyses and valuations, be somewhat as follows :-

$\begin{array}{llllll}\text { Organic matter (without nitrogen) } & \ldots & \ldots & \ldots & \ldots & 66 \cdot 50\end{array}$

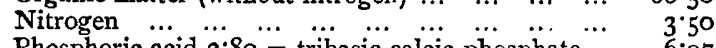

Phosphoric acid $\dddot{2} \cdot 80=$ tribasic calcic phosphate $\ldots \quad 6.6$ 6 70

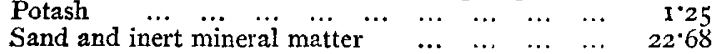

$\frac{22.68}{100 \% 00}$

In the debate which took place after the paper, Dr. Frankland, while admitting General Scott's process to be "worthy of trial," took exception to this estimate, and maintained that his experience was "that after the separation of detritus from London sewage, the maximum percentage of organic matter was 63 , whilst the minimum was 21 , the average being $39 \frac{1}{2}$, and these high percentages were obtained under exceptionally favourable circumstances, because, in the collection of these samples of sewage, little or none of the so-called detritus was mixed with it at all." He further stated that "he did not think it would be safe to calculate on more than 33 per cent. of organic matter in the dried sludge." This question of the possibility or otherwise of effecting a separation more or less perfect, of the mineral from the organic elements of the sludge lies at the root of General Scott's proposals, and while giving all due weight to Dr. Frankland's high authority, we are compelled to admit that General Scott's figures, many of them based on the analyses of Dr. Frankland himself, seem to point in the opposite direction to that pointed out by Dr. Frankland, as concerns the relative proportion of the mineral and the organic matters after settlement.

The question to be decided is, admitting the composition of the sewage solid to be in the first instance 2 mineral to I organic, can we reduce this proportion to 2 organic to I mineral, by bringing the sewage to a state of quiescence in tanks? This could be tried on a sufficiently large scale to settle the point at issue in a very short time, and as it is a question which to a great extent depends upon the result of actual experiment on a large scale, it is certainly one for the officers of the Metropolitan Board of Works to decide.

Passing over the theoretical values of the deposits, based upon their contents in nitrogen, phosphoric acid, and potash, which General Scott has dealt with very carefully, we come to the question of deodorising the sludge and its preparation as a manure. For the former purpose the employment of slaked lime is advocated, used in the small quantity of only $\cdot 66$, or less than $r$ per cent. of the total weight of the sludge. This slaked lime, made into milk of lime by the addition of water, is to be thoroughly incorporated with the sewage deposit, and a sufficient amount of crude superphosphate is then to be added, in order nearly, but not quite, to neutralise the lime. A crystalline precipitate of phosphate of lime is thus formed in the sludge, which greatly aids in the drying of the compound, or, to put it more correctly, facilitates the extraction of the water. Some of those who took part in the debate doubted whether General Scott, in his estimate of 20s. per ton on the dried material, which included the cost of chemical treatment, had made a sufficient allow. ance for the great labour and difficulty which would have to be incurred in drying the sludge for use as a manure. Dr. Voelcker, who pointed out that "he had gone very carefully into the figures in the paper, and was very glad to find that General Scott had avoided those exaggerations which frequently disfigured calculations of this kind," quoted some observations he had made tending to show that sewage sludge parted with water with extreme difficulty, though he admitted that after treatment with lime and phosphoric acid such sludge would dry with greater rapidity. In the various forms of filter presses now largely used for drying clay slip and expressing precipitates, very great improvements have recently been effected, and it has been stated on good authority that it becomes possible by their use to reduce the moisture in such materials as low as 50 per cent. There still remains, however, a large proportion of water to expel, and, as Dr. Voelcker stated, this can only be accomplished by means of artificial heat.

The question of the cost of drying sludge is one which possesses many features of interest, and the entire subject would be one well worthy of the special consideration of the Society of Arts at their annual conference on the treatment of sewage. We should like to have devoted more time to the calculations of General Scott of the theoretical value of the three chief fertilisers present in sludge, viz., nitrogen, phosphoric acid, and potash, as also to the expense of preparing soluble phosphoric acid, concerning which latter point Dr. Voelcker threw out some valuable suggestions during the discussion, but we must now conclude. We entirely agree with General Scott in his denunciation of the folly and imprudence of continuing to cast raw sewage into the Thames; he has certainly pointed out a way of greatly abating the present evil, and as the plan he advocates could be tried upon a sufficient scale at an almost nominal expense, we feel justified in urging with Dr. Frankland that this should be done, and we cordially echo his concluding observation, "that the Board of Works have no right to look for a profit in getting rid of the objectionable matter. If they can succeed in doing it without a loss or at a cost not greater than that involved in dredging it out of the river again, it ought to be done; because if sewage mud is deposited in the river there must be an obstruction to navigation, besides the putrefaction of organic matters which, when deposited on the banks of a tidal estuary, become very offensive, especially in warm weather."

So far as one can judge from the facts adduced by General Scott, his scheme promises to be more efficient for the ends aimed at than any hitherto proposed, and certainly it seems to us that the great scientific principles 
which are applicable to the subject have been kept well in view. And from our standpoint this must be the test of the efficiency of any scheme for the disposal of sewage. We fear that hitherto those with whom the decision rests as to what scheme shall be adopted for the disposal of the sewage of London have looked upon the question too much as one between rival "schemes," and considered far too much the supposed interests of rival "bodies," and too little the clear teachings of science and the welfare of the public. It is evident that for London, at least, the whole subject of the disposal of sewage will have very soon to be reconsidered, and we trust that the authorities concerned will take into their council reputable chemists and physicists, who we are sure, can have no interests more at heart than to see the unmistakeable teachings of science practically applied to the salvation of society.

\section{THE NEW WEALDEN DINOSAUR}

$\Delta \mathrm{T}$ the last meeting of the Geological Society, Mr. A J. Whitaker Hulke, F.R.S., brought forward some new facts concerning the remarkable Dinosaur Ornithopsis, which cannot fail to interest both geologists and naturalists.

In the original collection of Wealden fossils made by Dr. Mantell, and acquired for the British Museum, were two fragmentary bones, the nature of which was somewhat doubtful. Dr. Mantell regarded and figured one of these as a tympanic bone of Iguanodon, at the same time pointing out that it presented some resemblance to a vertebra. Prof. $R$. Owen adopted Mantell's views, and figured it as the tympanic bone of Iguanodon, or, perhaps, of Cetiosaurus or Streptospondylus.

In I869 Prof. H. G. Seeley pointed out that the fossil in question was undoubtedly a portion of a vertebra, and one of a new and very remarkable type. It exhibited points of comparison with the vertebræ of birds, in the lightness of its construction, and in the existence of great cavities penetrating into the centrum. Hence Prof. Seeley suggested for it the generic name of Ornithopsis.

In $1870 \mathrm{Mr}$. Hulke, who was at that time unaware of Prof. Seeley's determination of the vertebral character of the British Museum specimens, gave a description of the neural arch of a vertebra which he had discovered in the Wealden of the Isle of Wight. From the beautiful character of the groined entrance to the neural canal, Mr. Hulke was led to suggest the name of Eucamerotus as a provisional one for the new Dinosaurian genus which the specimen evidently represents.

He especially pointed out as of great interest the enormous size of these vertebræ, and the fact that they are built up of thin plates of very compact osseous tissue, with immense spaces of cancellous tissue between them. At a later date Mr. Hulke recognised the identity of his Eucamerotus with the Ornithopsis of Prof. Seeley.

In 1876 Prof. Owen again took up the study of the forms in the British Museum. He adopted Prof. Seeley's and Mr. Hulke's views as to the vertebral character of the fossils-but he rejected Prof. Seeley's generic narne on the ground that the resemblance between these vertebræ and those of birds is merely superficial, and that the name of Ornithopsis is therefore misleading. Prof. Owen described two new forms presenting this peculiar structure in the vertebral column, and to these he gave the names of Bothriospondylus and Chondrostosatmis; he insisted that the large cavities seen in the fossil vertebræ were probably originally filled with cartilaginous substance, as is the case in the sharks and rays, and argued, therefore, that any comparison with the vertebræ of birds was a misleading one. $\mathrm{Mr}$. Hulke and Prof. Seeley, however, while admitting that the structure does not necessarily imply the powers of flight in the forms possessing it, yet insist that in all probability the cavities in the vertebra were true air-cells, and therefore that the structure is "bird-like;" on these grounds they maintain that the name of Ornithopsis ought not to be superseded.

In I877 Prof. Marsh recognised among the numerous Dinosaurian remains obtained from Colorado a number of gigantic forms with vertebræ presenting the same peculiarities as are found in Ornithopsis; to these forms he gave the names Atlantosaurus, Morosaurus, Apatosaurus, Allosaurus, and Diplocus. Prof. Cope had simultaneously described three other forms-Camarasaurus, Amphicalias, and Epanterias, all presenting the same peculiarities as are found in the English form Ormithopsis. One of the American forms, Atlantosaurus had a femur seven feet in length. When the two distinguished American palæontologists visited this country in 1878 , they both recognised the specimens of Ornithopsis in Mr. Hulke's collection as presenting numerous points of resemblance with the new forms which they had described.

Now in the communication which he has recently made to the Geological Society, Mr. Hulke has described vertebræ from several parts of the spine of Ornithopsis. This he is enabled to do by the courtesy of the Rev. W. Fox, of Brixton in the Isle of Wight, who has long been such an indefatigable collector of the vertebrate fossils of the Wealden, and has permitted Mr. Hulke to make use of his materials. Mr. Hulke shows that while the dorsal vertebræ were closely bound together by processes, so that this part of the spine must have possessed great rigidity, as is the case with birds, the cervical vertebræ indicate the existence of the greatest mobility. But the point on which Mr. Hulke principally insists, from its bearing on the discussion whith has taken place between himself and Prof. Seeley, on the one hand, and Prof. Owen on the other, is that the cavities and cancellous tissue are confined to the dorsal vertebræ, and do not occur in the other portions of the spinal column; this he insists is inexplicable, if, as Prof. Owen insists, the cavities in question had no functional character, but were filled up with cartilaginous tissue, while it finds a ready explanation in the supposition of Prof. Seeley and himself that they are truly pneumatic cavities. Mr. Hulke also points out that there are reasons for believing that some at least of the vertebræ referred to the genus Cetiosaurus belong to the new group of forms to which so much attention has been directed during the last few years.

There can be no doubt that there existed during mesozoic times, both in this country and on the American continent, a group of reptiles of gigantic dimensions, which presented such peculiarities of structure, especially in their vertebral column, that they must be placed in a distant sub-order of the Dinosauria. For this, perhaps the name of Sauropoda, suggested by Prof. Marsh, may be adopted.

The existence of this bird-like character of pneumatic bones in reptiles of such gigantic dimensions as these peculiar Dinosaurs undoubtedly were is certainly very startling and unexpected. At the same time we believe that neither Prof. Seeley nor Mr. Hulke favours the idea that the forms in question were capable of flight. $\mathrm{Mr}$. Hulke promises shortly to add another to his valuable contributions to our knowledge of these forms by describing the limb-bones of Ornithopsis and its allies, and discussing the habits which a study of their structure seems to indicate. All geologists and naturalists will look forward eagerly for the promised memoir.

\section{CASSELL'S NATURAL HISTORY'}

THE third volume of this well-illustrated and popular account of the animal kingdom contains descriptions of the Ruminantia by the late lamented A. H. Garrod,

× Edited by P. Martin Duncan, M.B. (Lond.), F.R.S., F.G.S. Vol. iii. London: Cassell, Petter, and Galpin, 1879 .) 